\title{
THE INFORMAL ECONOMY OF CITIES IN THE SOUTH: THE CASE OF CALI, COLOMBIA
}

\author{
LINA MARTÍNEZ ${ }^{1} \&$ JOHN RENNIE SHORT ${ }^{2}$ \\ ${ }^{1}$ Universidad Icesi - POLIS, Colombia. \\ ${ }^{2}$ University of Maryland, Baltimore County, USA.
}

\begin{abstract}
This paper analyses the dynamics of the informal economy in Cali Colombia. In particular it details the working lives and characteristics of street vendors in the main food market of the city, Santa Helena. It compares them with formal merchants in the same area and uncovers a major difference in income. Street vendors make more money. Government interventions to revitalize the area and create a linear park that requires the market's transformation and street vendors' relocation may be undermined due to the high earnings and expectations of street vendors.

Keywords: Cali, Colombia, informal economy, public space, street vendors.
\end{abstract}

\section{INTRODUCTION}

The informal economy is an important part of the urban economy of the global South. Almost half of the working population in Colombia relies on the informal economy to obtain income [1]. Street vending is an important sector within this informal economy subject to a government agenda to regulate its expansion [2]. Street vending was historically defined in Colombia as an illegal appropriation of public space. However, in 2003 the Colombian Constitutional Court deemed street vendors as a vulnerable group and any action taken against their use of public space, was a violation of constitutional rights. The new law imposed limits on government control leading to a significant increase in the number of street vendors in large cities [3].

In many Colombian cities street vending expands with limited government control. One of the main interventions used by the government to decrease and control the number of street vendors invading public space involves the relocation of street vendors into regulated and formal commerce space $[3,4]$. This strategy has mixed results. In most cases, intervention has failed as street vendors returned to public space because of the poor sales and hence reduced incomes in the newly designated places [5].

In Cali, the third largest city in the country, street vendors' relocation was attempted in 2010 in the largest street vending settlement in the city. Results of this intervention, according to reports in local newspapers, are considered a failure [6]. The intervention was never formally evaluated by the government.

Due to a large urban planning project, local government is intervening in the largest food market of the city, Santa Helena. The government proposes to relocate the vendors. This analysis, aims to provide the background to this intervention by detailing the characteristics of vendors and merchants in Santa Helena. This study compares merchants located in formal settings (where relocation strategy would take place) and street vendors (those who will be relocated) on different dimensions. 


\section{LEGAL FRAMEWORK}

Street vending is a persistent phenomenon in the urban areas in Colombia since at least 1930. The government has tried to control its expansion. Two legal frameworks have defined street vending in Colombia. The first, Regulation and Control, lasted from 1932 to 2003. Under this framework, street vending was defined as an illegal occupation of public space. Additional regulations and controls were added in 1950, 1957 and 1964. During this time, the government took three main actions to regulate and control street vending: (i) issuing licenses to informal workers to allow public space use to conduct an economic activity without allowing a permanent occupation; (ii) construction of stalls in public areas that were then rented to licensed street vendors; and (iii) regulation of heavy traffic (pedestrian and vehicular) in spaces occupied by street vendors.

Police regularly removed street vendors occupying public space and fining those working without a license [3, 4]. In 1991, with the promulgation of the New Constitution, policy action and controls towards street vending were reinforced. Local governments were granted the legal duty to preserve the integrity of public space to ensure its use by all citizens and halt illegal appropriation. To fulfill this mandate, national and local governments were instructed to: take measures to avoid private appropriation of public space; use the police to clear streets in case of appropriation; and allow the economic activity of street vending only for those with a license. With this mandate, local governments took aggressive actions to remove street vendors from public space and abandoned the licensing strategy [4].

However, in 2003 after several lawsuits filed by street vendors claiming excessive use of force and violation of rights, the Constitutional Court revised and mandated new actions towards street vendors. A new Deregulated System emerged. National and local governments were mandated to promote the living conditions and to adopt measures to favor discriminated or marginalized groups. Under this revision, street vendors were protected by law and to remove them from the public space became a violation of their right to work.

With this shift in the legal framework, the government had to take a different approach to street vendors. No longer able to remove vendors from public space, other measures were taken. Relocation, work training, conditional cash transfers and assistance in creating new job opportunities were used by local governments [3]. Their effectiveness is not known since there are no evaluations of such interventions. What is known, however, is that street vending is an increasing issue in large cities in Colombia and because the appropriation of public space is now relatively easy, it has become an outlet of income generation for unemployed, displaced and handicapped population. Government action has been uneven across the country. Bogotá has implemented more measures to control this phenomenon.

The link between street vending with illegal activities and the operation of profitable business that generate negative externalities without being taxed, is now an important issue for public policy [7].

\section{SANTA HELENA MARKET}

Santa Helena market is the largest food retail open market in Cali, Colombia. It covers 12 blocks that includes both formal and informal commence. Little is known about the market's history. It is first referenced in 1962 as a building called "Santa Helena Market". It was constructed beside a busy railroad. In the building, merchants sold produce, fruits, vegetables and other edibles. Around the market as the population in the neighborhood grew, more street vendors appeared. More than 30 years ago the railroad ceased operations and the railway line was abandoned [8]. 


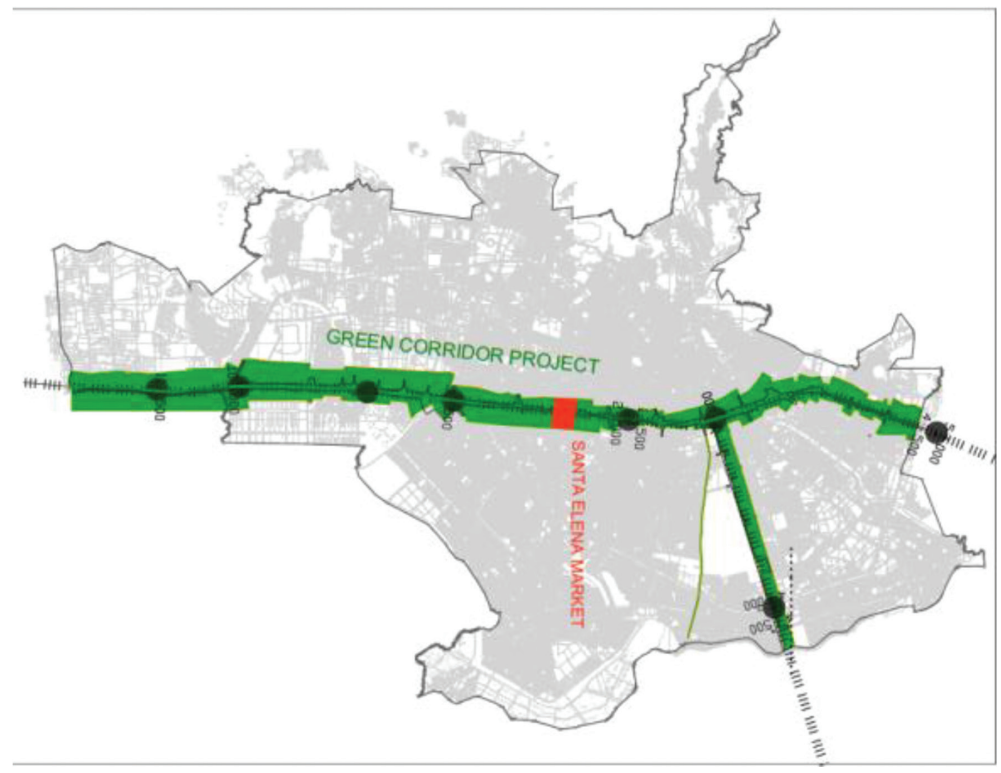

Figure 1: Green corridor project and Santa Helena Market.

Nowadays the market and its surroundings is a crowded area in one of the most violent areas of the city. There are many police claims of illegal activity both in the market and the surrounding slums. The Santa Helena Market building still hosts food merchants and street vendors abound in the sidewalks of the area.

The local government is trying to implement a large linear park in the city by revitalizing the abandoned railway line that runs right through the city. The "green corridor" initiative reuses the railroad infrastructure for light train public transportation [9]. Santa Helena market is located right in the middle of the project as shown in Fig. 1. On this map, the green line shows the proposed green corridor project and the red square locates the Santa Helena Market.

With the implementation of the green corridor project, Santa Helena Market is now the center of a debate of how to organize street vendors in the area. Local government has proposed to relocate all street vendors using and expanding the old Santa Helena Market building [10]. Under this plan, more than 100 street vendors that currently work in the area will be relocated to a formal setting using the building space where Santa Helena Market first emerged.

Street vendors oppose this measure alleging that relocation will significantly reduce their income because market's visitors prefer to buy in the streets where edibles are easily accessible more than visiting the building. In this analysis, information is provided to show that street vendors' claims are right, and their income would be significantly reduced in case of relocation in Santa Helena Market building.

\section{THE STUDY}

The data for this study comes from a direct survey of two groups of merchants in Santa Helena market: street vendors and traders located in the Santa Helena Market building. The objective of this comparison is to show that informal street vendors are obtaining higher economic returns that those located inside in a more formal setting. Therefore, relocation into the 
building to advance in the green corridor project, will have important consequences on their earnings and quality of life.

Detailed structured surveys were completed for 212 Santa Helena merchants, 112 located in public space (referenced as street vendors) and 100 located in the building (referenced as traders in buildings). Pollsters were hired and trained in using the questionnaires. There were also three pollster's supervisors in the field during data collection. Informants where randomly selected in all blocks and the survey was conducted while they were at their stall. Respondents were approached by explaining the objective of the study, assuring confidentiality and emphasizing that the data will be used for academic purposes. Also, it was made clear that they could stop the survey at any time and participation was voluntary. Respondents answered 68 questions concerning socioeconomic status, family composition, income (including sales and profits), education, life satisfaction and access to government welfare. Surveys were collected in January-February 2016. The study was conducted by the Observatory of Public Policy of Universidad Icesi and co-financed by the green corridor project.

In-depth interviews were also conducted with 9 street vendors. Surveys inquired about family composition, economic and social dimensions of working in Santa Helena and criminal activities in the area (bribes, payments for public space use and drug selling). Three government officials were also interviewed to gain information on planned and previous interventions aimed at recovering public space.

\section{THE RESULTS}

Table 1 presents a socioeconomic profile of traders in building and street vendors in Santa Helena Market.

\subsection{Similarities}

First, the similarities. Street vendors and merchants have a similar gender, age and disability challenge profile. About $76 \%$ of both traders in building and street vendors are the main bread winners in their households.

In terms of similar business practices, both buy merchandise daily for their business and more than $50 \%$ pay cash for this transaction. $83 \%$ of traders in building and $87 \%$ of street vendors are the only owners of the business. 61\% (traders in building) and 56\% (street vendors) are currently paying a loan. For both groups, more than $50 \%$ are repaying payday loans. In the interviews it was found that street vendors have to use payday loans because they do not have the minimum criteria to access formal banking services. Some reported that they accessed microfinance loans, because they defaulted on regulated banking services). They even have to use payday loans to pay micro-finance credit. The average interest rate reported for a payday loan was between $10 \%-15 \%$ daily. They also report the use of violence when not able to repay payday loans.

Traders and street vendors share similar views of Santa Helena. Both groups report that the main problem in the area is lack of safety and crime (26\%). Some noted that were charged a fee for using the public space (about a dollar a month). The fee was charged by "surveillance" (probably criminal gangs), and in some cases, the fee was charged by the owner of the formal business. Drug selling was recognized as a real problem in the market. Some also recognized that the surroundings are very dangerous. Other informants preferred not to talk about these issues. Some of the informants declared that during the last 5 years the market has experienced a permanent decline, due to violence and crime. At least $14 \%$ of merchants in the building consider that street vendors are the major problem in the area. 
Table 1: Socioeconomic profile of Santa Helena merchants.

\begin{tabular}{|c|c|c|c|}
\hline \multirow{2}{*}{ Characteristics } & \multicolumn{3}{|c|}{ St. Elena 2016} \\
\hline & Traders in building & Street vendors & Total \\
\hline Women $(\%)$ & 50 & 52 & 52 \\
\hline Average age (years) & 55 & 50 & 52 \\
\hline $\begin{array}{l}\text { High school or higher educational } \\
\text { attainment }(\%)\end{array}$ & 30 & 10 & 20 \\
\hline Civil status: marriage and cohabitation $\%$ & 60 & 47 & 53 \\
\hline Race: Black (\%) & 23 & 32 & 28 \\
\hline Race: Indigenous (\%) & 19 & 18 & 18 \\
\hline Average kids & 3 & 3 & 3 \\
\hline Average Income (\$ usd)* & 473 & 510 & 494 \\
\hline Daily hours of work (hours) & 8.3 & 10.2 & 9.3 \\
\hline Days worked by week (days) & 6.0 & 6.1 & 6 \\
\hline Street vendors with disability (\%) & 7 & 8 & 8 \\
\hline Union membership (\%) & 29 & 0 & 14 \\
\hline More than 5 years as street vendor $(\%)$ & - & 87 & 87 \\
\hline More than 5 years located at Santa Helena $(\%)$ & 89 & 79 & 84 \\
\hline
\end{tabular}

* 2,000 Colombian pesos for 1 US dollar

The poor sanitary condition of the market is also a factor highlighted and associated with the permanent decline. Vendors interviewed consider that people are no longer visiting the market because of lack of security and also because the formal economy is establishing large stores across the city with low prices for fruit and vegetables.

Despite all of this, both groups report very high levels of life satisfaction. More than $66 \%$ report feeling satisfied with their life (8 or higher in a scales of 1 to 10). In order to be completely satisfied, they want more money (40\%), home ownership (22\%) and good health $(14 \%) .48 \%$ in both groups consider that their economic condition has not improved during the last year. However, about $66 \%$ for both groups are satisfied with their actual living standard. 37\% (traders in building) and 50\% (street vendors) declare that they are better off than their parents. Street vendors are probably on a more accelerated track of social mobility, because of their returns from street vending.

\subsection{Differences}

Traders in building are better educated, more unionized and have a larger representation of whites than street vendors. The results confirm that the informal economy provides 


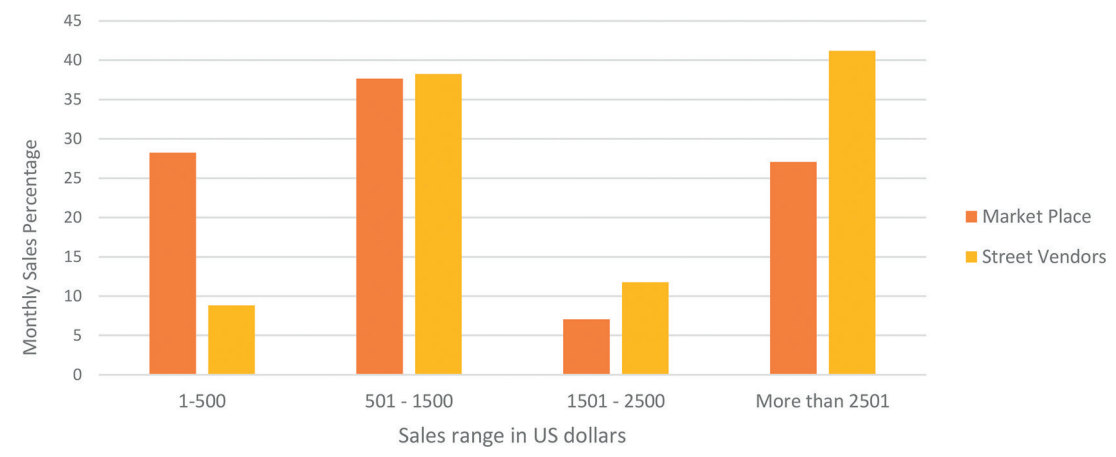

Figure 2: Average monthly sales.

opportunities for racial minorities and the less educated. The most striking feature is the difference in income. Street vendors make more than traders despite their lower educational attainment. And amongst those making more than U\$1,500 per month, the majority are street vendors. Differences in income are significant. For instance, street vendors report daily sales of U\$163, whereas traders in building report about 30\% less on daily sales (U\$113). Street vendors report monthly earnings (discounting price of merchandise and operating costs) of U\$832. Traders in building report close to half of this figure: U\$453 US dollars monthly.

Associated with this basic income disparity, $56 \%$ of traders in building and $62 \%$ of street vendors declare that their business provide the income necessary to cover basic needs on their households. $67 \%$ and $75 \%$ (traders in building and street vendors respectively) consider that this business has increased their income. Although vendors have higher incomes, this is purchased at the cost of tougher working conditions and permanent exposure to the increasing violence and bribes in the streets. Despite their higher incomes, $70 \%$ of street vendors would sell the business for about US\$5,000. Typical government intervention with this population (including training and money for creation of small business) is significantly less than the asking price of street vendors for their economic unit. Interviews with public servants reported that during 2014 government invested about US $\$ 1,000$ in training and seed money for each trash picker. A similar amount may be expected for an intervention with street vendors.

Although street vendors have higher income, because of their lower socioeconomic position, they are less able to accumulate assets now or in the future: $48 \%$ of merchants in the building are household owners, but only $19 \%$ of street vendors. $79 \%$ of street vendors uses the national health services for the poor, $57 \%$ of traders in building do. $15 \%$ of traders in building save for retirement, only $3 \%$ of street vendors do. These important differences point to the vulnerability of street vendors and their dependence on daily income to subsist. Despite higher incomes they are unable to capitalize and create a plan for the future using their earnings.

We asked vendors about their attitudes to relocation. $44 \%$ of street vendors reported that they would accept relocation by the government. A third would abandon the public space if they receive a subsidy similar to their current earnings. Given the important differences in income between traders in building and street vendors it is understandable why street vendors would oppose relocation measures. Because the actual investment in government for income generation alternatives (using trash pickers intervention as a proxy), is so much lower, it is easy to see why past alternatives have failed. 


\section{CONCLUSIONS}

Both vendors and traders inside the building have a tough job. Working schedules do not contribute to family cohesion. Many start working at midnight while others start at 2:00 a.m. in the morning and most work until 1:00 p.m. The condition of the market and the surrounding area are deteriorating in terms of the relative advantage compared to stores across the city and in terms of basic safety and security.

In a surprising result, the survey found that street vendors, on average, make more money than the traders in the building. Street vending provides an example of relatively high incomes for moderately educated people. It is a route to income generation denied in the formal economy. However, this also means that vendors are likely to resist relocation if the site is redeveloped. Result suggests that government compensation needs to be more realistic and linked to the actual incomes generated.

The long-term future of the area is under a cloud. And so it is not surprising that almost half of vendors would accept relocation by the government, although their actual response will depend on the place of relocation and the accompanying compensation. The difference between what vendors will accept and what the government offers may be too large for a successful relocation program.

\section{REFERENCES}

[1] DANE (National Administrative Department of Statistics), Medición del Empleo Informal y Seguridad Social, available at: http://www.dane.gov.co/files/investigaciones/boletines/ech/ech/bol_eje_informalidad_may_jul_15.pdf.

[2] Gómez, L., Huertas, G. \& Olea, D., Desafíos de la Modernización y Sector Informal Urbano. El Caso de Colombia, Documentos de la OIT, No. 87, 1998.

[3] Castañeda, A. \& García, J., Hábitat y espacio público. El caso de los vendedores informales en el espacio público físico de Bogotá, Alcaldía Mayor de Bogotá, Secretaría de Gobierno, Instituto para la Economía Social, PNUD, ONU-Hábitat, 2007.

[4] Donovan, M.G., Informal cities and the contestation of public space: the case of bogota's street vendors, 1988-2003. Urban Studies, 45(1), pp. 29-51, 2008. http://dx.doi.org/10.1177/0042098007085100

[5] La Vanguardia, A un año del despeje, la reubicación de ambulantes en Bucaramanga es un fracaso, 2014, available at: http://www.vanguardia.com/santander/ bucaramanga/241937-a-un-ano-del-despeje-la-reubicacion-de-ambulantes-en-bucaramanga-es-un-

[6] El Tiempo, Espacio público: vendedores informales invaden el centro de las ciudades, 2013, available at: http://www.noticiascolombianas.com.co/index.php/31449/espaciopublico-vendedores-informales-invaden-el-centro-de-las-ciudades/

[7] Revista Semana, Vendedores ambulantes por doquier, 2014, available at: http://www. semana.com/nacion/articulo/en-bogota-vendedores-ambulantes-por-doquier/390120-3

[8] Silvia, M.R., Las historias que habitan en los olvidados rieles y vagones del Ferrocarril de Cali, 2012, available at: http://www.elpais.com.co/elpais/cali/noticias/historias-habitan-en-olvidados-rieles-y-vagones-del-ferrocarril-cali

[9] Planeación Municipal, Plan de Ordenamiento territorial de Cali - POT, 2014. Alcaldía de Cali, 2014.

[10] El País, Pondrán acelerador a intervención de la galeria Santa Elena, 2016, available at: http://www.elpais.com.co/elpais/cali/noticias/pondran-acelerador-intervenciongaleria-santa-elena 